\title{
Infrared thermography to evaluate pain in a multiple sclerosis patient. Case report
}

\author{
Termografia por infravermelho na avaliação da dor em paciente com esclerose múltipla Relato \\ de caso
}

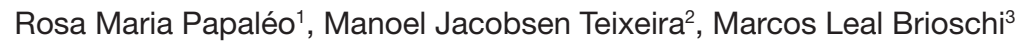

DOI 10.5935/1806-0013.20160078

\section{ABSTRACT}

BACKGROUND AND OBJECTIVES: Multiple sclerosis is an autoimmune, inflammatory, demyelinating and chronic disease of the central nervous system. As from the understanding of its pathophysiology and of thermoregulating dysfunctions caused by the disease, it is clear that, whenever possible, infrared thermography should be done. Thermography helps understanding how the disease affects different body areas, by investigating asymmetries, contractures and neurogenic patterns. This study aimed at documenting by infrared thermography a case of multiple sclerosis in crisis of pain.

CASE REPORT: Female patient, 63 years old, diagnosed with multiple sclerosis in 2007 after magnetic resonance and lumbar puncture. Six month ago she started complaining of progressive decrease in lower limbs muscle strength in addition to increased spinal pain, especially in lumbar spine and right hemibody. $\mathrm{Pa}-$ tient was submitted to new exams (head and cervical spine resonance), which have shown the same pattern found in previous exams, resulting from old injuries by demyelinating substract. Thermometry has shown asymmetry of the whole right hemiboby with central neurogenic patterns and temperature difference $\left(\Delta \mathrm{T} 0.8^{\circ} \mathrm{C}\right)$, thus confirming initial diagnosis. With regard to major complaint, there was asymmetry between paralumbar regions and presence of lumbar paravertebral hyperradiation, suggesting local muscles contracture.

CONCLUSION: Multiple sclerosis has a wide range of symptoms, especially the installation of chronic pain and inadequate thermoregulation, which directly interfere with quality of life of patients.

Keywords: Lumbar pain, Multiple sclerosis, Thermography.

\footnotetext{
1. Universidade de São Paulo, Faculdade de Medicina, São Paulo, SP, Brasil.

2. Universidade de São Paulo, Faculdade de Medicina, Hospital das Clínicas, Departamento de Neurologia, São Paulo, SP, Brasil.

3. Universidade de São Paulo, Faculdade de Medicina, Hospital das Clínicas, Coordenador da Especializaçăo em Termologia e Termografia, Săo Paulo, SP, Brasil.

Submitted in October 27, 2015.

Accepted for publication in June 23, 2016.

Conflict of interests: none - Sponsoring sources: none.

Correspondence to:

Av. Dr. Arnaldo, 455 - Cerqueira César

01246-903 São Paulo, SP, Brasil.

E-mail: rosapapaleo@uol.com.br

(C) Sociedade Brasileira para o Estudo da Dor
}

\section{RESUMO}

JUSTIFICATIVA E OBJETIVOS: A esclerose múltipla é uma doença autoimune, inflamatória, desmielinizante e crônica do sistema nervoso central. A partir do entendimento da sua fisiopatologia e das disfunçóes termorreguladoras decorrentes da doença, fica claro que quando possível, a termografia por infravermelho deve ser feita. A termografia facilita o entendimento de como a doença atinge as diversas áreas do corpo, investigando assimetrias, contraturas e padróes neurogênicos. O objetivo deste estudo foi documentar por termografia infravermelha um caso de esclerose múltipla em crise álgica.

RELATO DO CASO: Paciente do gênero feminino, 63 anos, diagnosticada com esclerose múltipla em 2007, após realização de ressonância magnética e punção liquórica. Ha seis meses começou a queixar-se de diminuição de força muscular nos membros inferiores de caráter progressivo, além de aumento nas dores da região da coluna vertebral, principalmente na coluna lombar e no dimídio direito. Realizou novos exames (ressonância de crânio e coluna cervical), que mostraram o mesmo padrão encontrado em exames anteriores, resultantes de lesóes antigas por substrato desmielinizante. A termometria demonstrou assimetria de todo hemicorpo direito, com padrão neurogênico central, e diferença de temperatura $\left(\Delta \mathrm{T} 0,8^{\circ} \mathrm{C}\right)$, confirmando assim o diagnostico inicial. Em relação à queixa principal, foram encontradas assimetria entre regióes paralombares e presença de hiper-radiaçáo paravertebral lombar, sugerindo contratura da musculatura local.

CONCLUSÁO: A esclerose múltipla possui vastos sintomas, destacando-se aqui a instalaçáo de quadros álgicos crônicos e termorregulação inadequada que interferem diretamente na qualidade de vida de seus portadores.

Descritores: Dor lombar, Esclerose múltipla, Termografia.

\section{INTRODUCTION}

Multiple sclerosis (MS) is an autoimmune disease affecting the central nervous system (CNS), more specifically the white matter, causing demyelination and inflammation. It usually affects more females than males, aged 20 to 40 years, but there have been also cases outside these limits. Females are more likely to develop MS as compared to males in a ratio of three females for each male. In Brazil, its prevalence is approximately 15 cases for every 100 thousand inhabitants ${ }^{1,2}$. 
There are four types of clinical evolution: remittent-recurrent (RR-MS), primarily progressive (PP-MS), primarily progressive with outbreak (PP-MS with outbreak) and secondarily progressive (SP-MS). Most common type is RR-MS, representing $85 \%$ of all cases at onset ${ }^{3,4}$.

There are many MS symptoms which affect each individual differently. They vary according to the magnitude of nervous injury and to where in the CNS it has occurred. MS individuals may experience virtually any neurological sign or symptom, including alterations: 1) sensory or motor, such as loss of tactile sensitivity or tingling, paresthesia, muscle fatigue, muscle spasms; 2) in coordination and balance (ataxia); 3) in speech (dysarthria) or swallowing (dysfagia); 4) visual such as phosphene, diplopia, nistagmus, in the sequence of optic neuritis. Fatigue, acute or chronic pain and urinary and bowel movement difficulties, the latter with secondary constipation ${ }^{5,6}$.

Although not exclusive to MS, there are also Uhthoff phenomenon, worsening of symptoms due to exposure to temperature higher than normal, and Lhermitte signal, sensation of electric current irradiating through the spine when binding the neck ${ }^{6}$. Diagnosis is primarily based on reviewed McDonald criteria ${ }^{7}$, being these adopted by the world scientific community to diagnose MS. Brain magnetic resonance (MRI) shows injuries typical of deymelination. For being a very broad differential diagnosis and having a variety of symptoms, new complementary evaluation methods may be used, such as digital infrared thermography.

As decribed by Brioschi ${ }^{8} \&$ Brioschi, Lin $\&$ Teixeira $^{9}$, this is a noninvasive method to evaluate skin neurovegetative system by mapping thermal distribution, which does not require contrast or physical contact with patients, the results of which allow determining the functioning of vascular, nervous and musculoskeletal systems, of inflammatory, dermatologic, endocrine and oncologic processes. Thermal image is changed in cases of disease and functional and structural alterations, reflecting abnormal thermal patterns, such as areas of hypo or hyper-radiation, thermal asymmetry between contralateral body regions or hemibodies with temperature differentials above $0.3^{\circ} \mathrm{C}^{10,11}$. Taking this aspect into consideration, thermoregulatory dysfunction in MS patients should not be neglected, being primarily induced by immaturity of CNS cooling system. This system works as from a complex vascular network in face and skull, closely linked to inner brain. Repercussions of such system immaturity are complex, from mere difficulty in taking warm bath to major risk factor of sudden death in this population when individuals are exposed to high temperatures ${ }^{12}$. Knowing this, it is possible to notice the usefulness of the study of thermoregulation in this population since the onset of the disease ${ }^{13}$. Ueno et al. ${ }^{14}$ have performed thermography in a child diagnosed with MS and complaining of unilateral sweating. Another study from the 1960s has shown asymmetric temperature pattern in MS patients ${ }^{15}$, however this was only evaluated in the face and diagnostic impressions are not clearly described, making difficult the comparison with current studies. In addition to these, a recent literature review recommends the use of thermography in the clinical practice in patients with neuro- logical disorders, where it may be used as auxiliary diagnostic tool or as method for clinical follow up of the disease ${ }^{13}$. Other thermographic studies in this population have not been found. So, as from results, the investigation of thermoregulation changes and of the relationship with neurovegetative system may open a new study field around MS pathophysiology. So, this study aimed at documenting with infrared thermography a case of MS with pain crisis.

\section{CASE REPORT}

Female patient, 63 years old, since 2007 started to have severe pain in cervical and lumbosacral spine, with episodes of numbness in upper (UULL) and lower (LLll) limbs, which have evolved to strength deficit during the practice of exercises and gait changes (shift to the left and widening of the base), suggesting balance disorders.

In this year, after consultation with a neurologist, she was submitted to cervical magnetic resonance (MRI) which has evidenced mild signs of degenerative disc disease, evidences suggesting demyelinating disease, involving cervical spinal cord. Presence of vertebral hemangioma in vertebral body T1; skull MRI showing multiple images compatible with zones of magnetic signal changes in supratentorial white matter, predominantly located close to corpus callosum and frontal regions, the largest to the right, with hyposignal in T1 and hypersignal in long TR sequences, which is compatible with demyelinating injuries. This MRI has shown good alignment of vertebral elements without bony elements conformation changes, focuses of fatty tissue deposition inL3 and L4. Decreased height and signal of intervertebral discs L4/L5 and L5/S1 in T2 images with mild signal modification in the anteroinferior rim of L4 and anterosuperior of L5 due to degenerative subchondral change. Spinal canal and conjugation foramina with good amplitude. Conus with normal signal shape, situation, dimensions and intensity. Joint processes and pre and paravertebral elements without apparent anatomic changes. Lack of abnormal postcontrast enhancements. No signs of posterior disc protrusion indicative of disc hernia. CSF puncture was also performed which has shown absence of neoplastic cells and negative biochemistry for viral infections. Non-reagent VDRL.

After ruling out other possible diseases and relating to symptoms referred by patient and to recurrence of episodes in previous months, MS was diagnosed and treatment was started. Patient started using interferon 44 associated to baclofen (antispasmodic) and fluoxetine, being referred to physiotherapy, occupational therapy and psychology. Currently patient is using natalizumab to replace interferon.

In following years, patient has evolved with intermittent outbreaks, after which she referred increased spasticity and motor and strength deficits, associated to severe muscle pain, especially in lumbar spine, in addition to urinary tract alteration. She continued making annual MRI exams to control evolution of injuries: skull MRI in 2009 has shown clear decrease in the number and dimensions of referred images without signs of enhancement suggesting activity. 
Skull MRI in 2010 has shown T2 images with areas of hypersignal in white matter of brain hemispheres in paracallosum and periventricular situation, being of interest corpus callosum and callosum-septal interface some of them with areas of hyposignal in T1 and, which for their disposition, show disease with demyelinating substrate. There is moderate widening of cortical sulci in the convexity of brain hemispheres and Sylvian fissures, with brain ventricles with normal dimensions. Lack of extra-axial fluid collections.

Skull MRI in 2011 has shown areas of hypersignal in callosum and paracallosum situation, well suggestive of MS, without relevant changes in posterior fossa, presence of a very subtle area of hypersignal in the bulb-medullary transition, in midline, however slightly more to the right, which should correspond to a demyelinating injury. Cortical sulci, basal cisterns and brain ventricles with normal amplitude and dimensions. Six months ago patient started to complain of progressive decrease of muscle strength in LLll, in addition to increased spinal pain, especially in lumbar spine and right hemibody. Under antidepressants, ansiolytic and anticonvulsants.

Patient was submitted to new exams (skull and cervical spine MRI), which have shown the same pattern found in previous exams, resulting from older injuries by demyelinating substrate. So, we decided to perform total body skin thermography to clarify diagnosis and lumbar pain screening.

\section{Description of skin thermometry technique}

Exam was started after patient's thermal stabilization, and for such she remained naked for 15 minutes in thermally controlled environment $\left(23^{\circ} \mathrm{C}\right)$, with minimum air convection $(0.2 \mathrm{~m} / \mathrm{s})$ and relative humidity below $60 \%$. Equipment was a FLIR brand infrared camera, modelT 420 , focus of $25^{\circ} 60 \mathrm{~Hz}$ with long infrared Wi-fi, $7.5-13 \mathrm{~m}$, spatial resolution of 1.36 mrad, thermal sensitivity of $0.045^{\circ} \mathrm{C}$ and resolution $320 \times 240$. With the patient in the standing position, 45 neurovascular territories were bilaterally analyzed, in each hemibody, totaling 90 territories.

\section{Diagnostic impression}

Thermometry has shown asymmetry of the whole right hemibody, with central neurogenic pattern (Figure 1) and temperature difference $\left(\triangle \mathrm{T} 0,8^{\circ} \mathrm{C}\right)$, symmetry in medial eye corners, internal carotid extracranial terminal branches territory, well delimited and homogeneous symmetric periocular hyperradiation, thermal asymmetry of the whole hemibody, head, trunk and extremities, asymmetry between posterosuperior cervical faces. Presence of extensive linear hyper-radiation, in descending and oblique band, with well-delimited isothermal distribution, on projection of posterior cervical muscles, thus confirming MS-induced thermoregulatory dysfunction.

With regard to lumbar spine pain (Figure 2), images analysis has shown paralumbar regions asymmetry. Presence of lumbar paravertebral linear vertical hyper-radiation, with ill-defined borders, irregular thermal distribution in paralumbar region, suggesting contracture of posterior cervical muscles and of lumbar paravertebral region (osteoarthropathy).

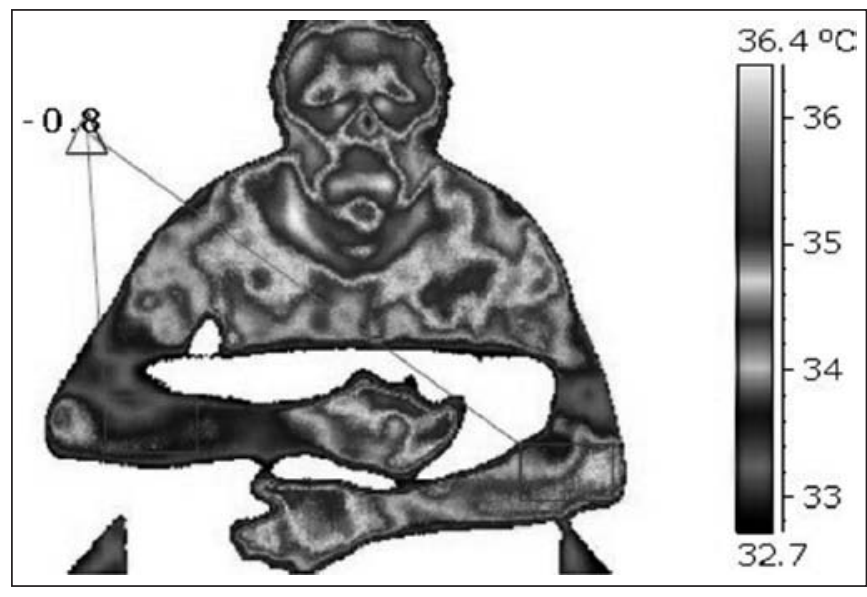

Figure 1. Infrared image showing central neurogenic pattern with temperature difference of $0.8^{\circ} \mathrm{C}$

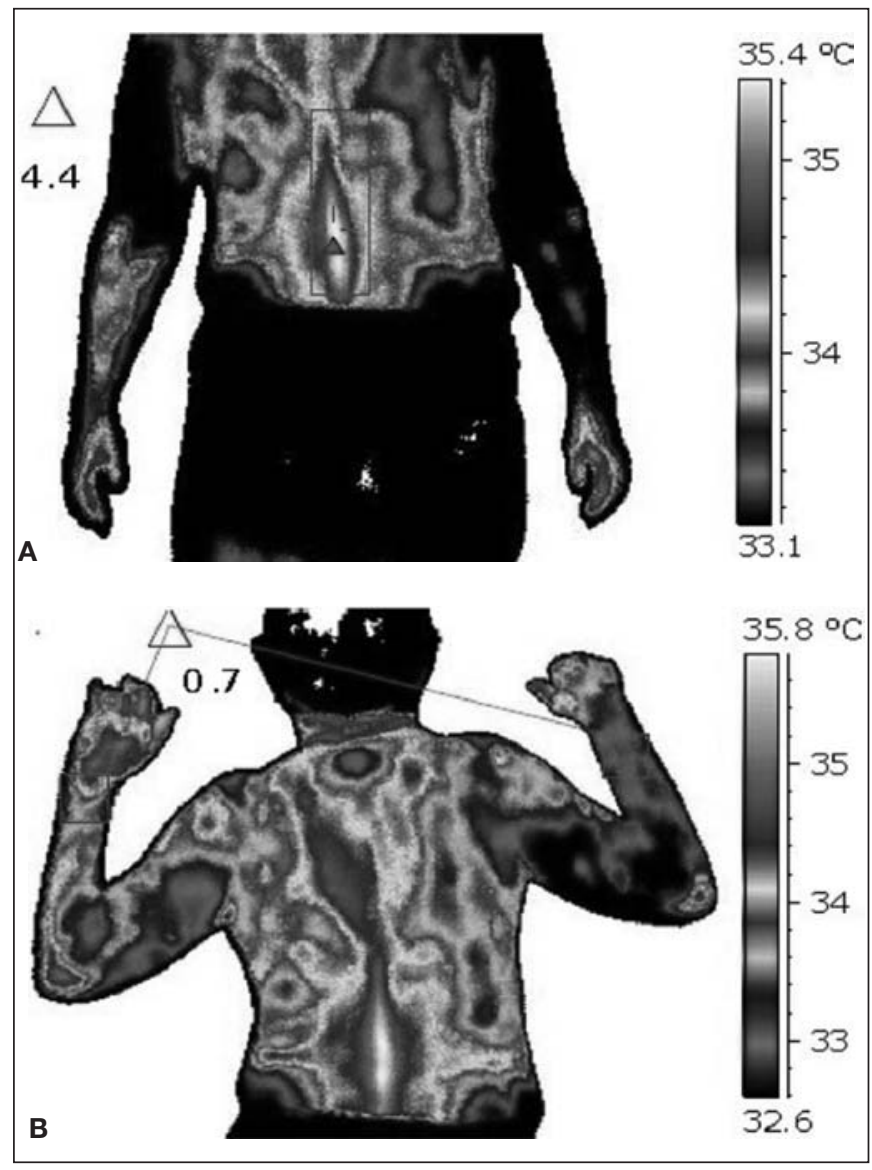

Figure 2. A. Infrared image showing lumbar paravertebral hyper-radiation and irregular thermal distribution. B. Image showing asymmetry between hemibodies and cervical spine hyper-radiation area, suggesting posterior muscles contracture.

\section{DISCUSSION}

Irregular thermal distribution suggestive of posterior muscles contracture could explain patient's severe pain. Pain evaluation is still a challenge because it is unique to each individual, and most available evaluation methods are very subjective. 
However, thermography may be applied with this objective ${ }^{16}$, since studies using thermal distribution evaluation by means of thermography in the investigation of pain episodes, including of neurological origin, are many and increasing, and their results have been proven, even comparing them to other already consolidated evaluation methods $s^{16-18}$.

A study with 65 chronic low back pain patients which related thermography to other imaging exams, has shown that infrared thermography showed abnormal thermal pattern in $92 \%$ of cases, while MRI has shown structural changes in $89 \%$, computerized tomography (CT) in $87 \%$ and myelography in $80 \%$ of patients. From 22 patients with positive disc alteration in MRI, 21 have shown thermographic changes and all cases with root involvement in CT and myelography have shown significant changes in thermography, especially in LLIl ${ }^{19}$.

However, it has to be stressed that changes in local temperature are not always reflex of installed painful processes, and inadequate motor activity resulting from sympathetic influences might be present ${ }^{11,20}$. Thermography has shown significant thermal asymmetry in the patient, with central neurogenic pattern, by involving right hemibody (face, trunk and extremities). Similar case was reported in a study ${ }^{14}$ with a child with MS, who presented excessive sweating on right face and shoulder. Unilateral hyperhydrosis of the whole hemibody is a central neurovegetative phenomenon which, comparatively, is similar to skin vasomotor change found in this patient. However, temperature changes were not evidenced by thermography, which makes this study the first to describe this phenomenon in case of MS.

Hyperhydrosis may be associated to hypothermia in some MS cases, as described by other studies ${ }^{21-23}$. Authors suggest that these symptoms, in addition to peripheral vasoconstriction, are associated to hypothalamic injuries, because this is the region controlling normal physiologic body responses to temperature changes. However, MRI images are not always able to detect changes in this brain region, making difficult the identification of the origin of thermal changes in MS patients, as well as their repercussions.

\section{CONCLUSION}

MS is still one medical mystery; it is not avoidable or curable and has broad symptoms, especially chronic pain and inadequate thermo-regulation, which directly interfere with quality of life of patients. To adequately treat the disease, it is necessary a correlation between symptoms and imaging exams results and in this case thermography would act as complementary diagnostic method, since many diseases result in similar pain presentations, however with temperature pattern different from MS, such as CNS infections, radiculopathies, fibromyalgia, among others ${ }^{24}$. In addition, another objective would be to screen painful acute and chronic symptoms, helping the understanding of the symptoms of the disease.

\section{REFERENCES}

1. Associaçăo Brasileira de Esclerose Múltipla - ABEM [Homepage na internet]. O que é esclerose múltipla? [acesso em 27 de dez de 2015]. Disponível em: www.abem.org.br

2. Callegaro D, Goldbaum M, Morais L. The prevalence of multiple sclerosis in the city of São Paulo, Brazil. Acta Neurol Scand. 2001;104(4):208-13

3. Fragoso YD, Peres M. Prevalence of multiple sclerosis in the city of Santos, SP, Brazil. Rev Bras. Epidemiol. 2007;10(4):479-82.

4. Ferreira ML, Machado MI, Vilela ML, Guedes MJ, Ataíde L Jr, Santos S, et al. [Epidemiology of 118 cases of multiple sclerosis after 15 years of follow-up on the reference center of Hospital da Restauração de Pernambuco, Brazil.] Arq Neuropsiquiatr. 2004;62(4):1027-32. Portuguese.

5. Milo R, Kahana E. Multiple sclerosis: geoepidemiology, genetics and the environment. Autoimmun Rev. 2010;9(5):A387-94.

6. Rudick RA. Esclerose múltipla e distúrbios relacionados. In: Goldman L, Bennett JC. (editores) Cecil: tratado de medicina interna. $21^{\text {a }}$ ed. Rio de Janeiro: Guanabara Koogan; 2001. 2387-96p.

7. Polman CH, Reingold SC, Edan G, Filippi M, Hartung HP, Kappos L, et.al. Diagnostic criteria for multiple sclerosis: 2005 revisions to the "McDonald Criteria". Ann Neurol. 2005;58(6):840-6.

8. Brioschi ML. Metodologia de normalização de análise do campo de temperaturas em imagem infravermelha humana. Curitiba. [Engenharia Mecânica]. Universidade Federal do Paraná; 2011.

9. Brioschi ML, Lin TY, Teixeira MJ. Estudo da dor por imagem infravermelha. Rev Dor. 2005;6(3):589-99.

10. Brioschi ML, Yeng LT, Pastor EM, Colman D, Silva FM, Teixeira MJ. Documentação da síndrome dolorosa miofascial por imagem infravermelha. Acta Fisiátrica. 2007;14(1):41-8.

11. Uematsu S, Jankel WR, Edwin DH, Kim W, Kozikowski J, Rosenbaum A, et al. Quantification of thermal asymmetry Part 2: Application in low-back pain and sciatica. J Neurosurg. 1988;69(4):556-61.

12. Baker DG. Multiple sclerosis and thermoregulatory dysfunction. J Appl Physiol. 2002;92(5):1779-80

13. Neves EB, Alves JV, Rosa C, Reis VM. Thermography in neurologic practice. Open Neurol J. 2015;9:24-7.

14. Ueno M, Tokunaga Y, Terachi S, Gondo K, Hara T. Asymmetric sweating in a child with multiple sclerosis. Pediatr Neurol. 2000;23(1):74-6.

15. Goldberg HI, Heinz ER, Taveras JM. Thermography in neurological patients. Preliminary experiences. Acta Radiol Diagn.1966;5:786-95.

16. Marcos ML, Abramavicus S, Corrêa CF. Valor da imagem infravermelha na avaliação da dor. Rev Dor. 2005;6(1):514-24.

17. Brioschi ML, Yeng LT, Teixeira MJ. Diagnóstico avançado em dor por imagem infravermelha e outras aplicaçôes. Prática Hospitalar. 2007;50(IX):93-8.

18. Lima RP, Brioschi ML, Teixeira MJ, Neves EB. Análise termográfica de corpo inteiro: indicaçôes para investigação de dores crônicas e diagnóstico complementar de disfunçôes secundárias. Pan Am J Med Thermol. 2015;2(2):70-7.

19. Thomas D, Cullum D, Siahamis G, Langlois S. Infrared thermographic imaging, magnetic resonance imaging, CT scan and myelography in low back pain. Br J Rheumatol. 1990;29(4):268-73

20. Kurz A, Sessler DI, Tayefeh F, Goldberger R. Poikilothermia syndrome. J Intern Med. 1998;244(5):431-6.

21. Edwards S, Lennox G, Robson K, Whiteley A. Hypothermia due to hypothalamic involvement in multiple sclerosis. J Neurol Neurosurg Psychiatry. 1996;61(4):419-20.

22. Darlix A, Mathey G, Monin ML, Sauvée M, Braun M, Schaff JL, et al. Hypothalamic involvement in multiple sclerosis. Rev Neurol. 2012;168(5):434-43.

23. Martinez-Rodriguez JE, Munteis E, Roquer J. Periodic hyperthermia and abnormal circadian temperature rhythm in a patient with multiple sclerosis. Mult Scler. 2006;12(4):515-7.

24. Rocha FC. Esclerose Múltipla. Academia brasileira de neurologia. [acesso em: 23 de abril de 2016]. Disponível em: http://www.cadastro.abneuro.org/site/conteudo. asp?id_secao=31\&id_conteudo=59\&ds_secao=Perguntas e Respostas. 